\title{
Economic Diplomacy in the Innovation Global Value Chains as the National Security Providing Strategy Component
}

\section{Vitaliy Omelyanenko ${ }^{1}$}

${ }^{1}$ Sumy State University

2 Rymskogo-Korsakova Street, Sumy, 40007, Ukraine, sumyvit@yandex.ua

DOI: $10.22178 /$ pos.20-3

JEL Classification: D46, 03

Received 3.03.2017

Accepted 17.03.2017

Published online 20.03.2017

(C) 2017 The Author. This article

is licensed under a Creative

Commons Attribution 4.0

License @) (1)

\begin{abstract}
The article deals with the analyzes of economic diplomacy application in the area of innovations. The strategy of economic diplomacy by improving the efficiency in global value chain participation was considered. The main effects of commercial diplomacy using in the innovation area was identified. The world experience using economic diplomacy in the innovation sphere was considered.
\end{abstract}

Keywords: economic diplomacy; global value chain; international cooperation; innovation; image.

\section{Introduction}

In the conditions of the global competition and the lack of development resources, the implementation of large innovation projects and the promotion of their results to the world market often is possible only within the framework of transnational research and production chains, based on cooperation. In this regard, the development of the international cooperation in the field of innovation system processes is one of the priorities of the modern state policy.

USA President Barack Obama in his 2nd inaugural address (January 20, 2013) has said, that "America's possibilities are limitless, for we possess all the qualities, that this world without boundaries demands: youth and drive; diversity and openness; an endless capacity for risk and a gift for reinvention" [1]. These words underline current trends, when USA still is an enormous innovation leader, but also has the great opportunity to obtain benefits from innovation taking place around the world.

In this case the economic diplomacy as a specific area of the modern diplomatic activity is connected with the current economic problems of state and is used by means of an object and has some sense according to the problem and strategy contest and cooperation within the international relations. The economic diplomacy pre- supposes diplomatic actions, oriented to increase export, to involve foreign investments and to participate in the work of the international economic organizations, i.e. actions, concentrated to confirm economic interests of the country at the international level. Economic diplomacy is manysided and includes several types of components, strategies and tools which are different by specialized spheres of application in policy and content of solving nation's tasks, specific nature of diplomatic impact means and methods, another economic features and peculiarities.

At the same time economic diplomacy is intended to use opportunities of traditional diplomacy and business-community structures to achieve at once foreign economic and political purposes. Therefore advancing the proper economic interests inside the country and abroad, the state uses its native resources, traditional diplomacy methods, its infrastructure and tools, and also modern informational means through the publications and speeches.

Unless there are many studies of the economic diplomacy problems, one has to point out, that economic diplomacy implementation within the innovation development strategy requires additional studies in the theoretical and methodic area, based on innovation globalization trends, innovation processes complexity, innovations 
significance for economic development and innovations globalization tendencies. However it is well-known, that the investigation and innovation commercialization intensity nowadays determines the status of state in the international relations.

\section{Revive of recent studies}

According to the Global Innovation Index 2015: Effective Innovation Policies For Development [2] the modern dynamic innovators (countries, which achieve higher results in comparison with other countries with the same level of GDP) receive more results in the innovations field owing to improving of innovations infrastructures and higher integration in global credit-investment and commodity markets. All these directions provide the international element, which is significant for the integration into the global high technological $R \& D$ and product markets. In our previous studies [3] we have considered the participation in the GVCs as the development capacity factor.

J. Leijten [4] notes, that in recent years innovation has become a topic in foreign affairs and in the practices of diplomacy. In the context of innovation diplomacy researcher consider the cases of solar photovoltaics as a field for global competition and collaboration and clusters, regions and "innovation cities" as new actors in the field.

Experts of Briges in topical studies collection [5] underlines, that in this regard, the development and adoption of the additional policies and measures, that promote not only the entry of local firms into the existing GVCs, but also the formation of the new production chains is important. At the same time, such measures should be coordinated with the overall development strategy of country. Through the participation in the GVCs, developing countries and countries with economies in transition have the opportunity to integrate into the world economy at low cost. However, do not expect that the benefits will be automatic. Much depends on the level of the chain at which the company operates. Typically, firms from the developing countries begin to participate in the GVCs at the bottom of the chain, at the production stages, where relatively small part of the value added is generated. To obtain the greater benefits for nation, it is necessary to move to higher levels of the chain. Thus, firms and countries compete with each other both for participation in the GVCs, and for higher positions in them.

S. Stephenson [6] concludes, that in an economically interdependent world the importance of GVC continues to grow, so legislators need to understand the full implications of this process, especially for economic and trade policies.

In our previous studies $[7 ; 8 ; 9 ; 10]$ we have considered communication aspects of international inter-cluster cooperation in high-tech industries and international innovation networks, which have an impact on innovation priorities optimization in the context of national technological security ensuring.

Another precondition for international economic diplomacy in innovations can be found in study of H. Chesbrough [11], California University Professor, in which has concluded, that "it is impossible to make all smart guys work for you - and then you need to learn how to work with smart guys both inside and outside your company". Consideration of this factor can provide the new tools of international innovation process management at the different levels and especially in the level of the nation`s competitiveness.

Based on the understanding the fact, that the economic diplomacy as a phenomenon is based on the three components (institutions and infrastructure, world's economic weight (power) in the world and set of diplomacy tools) [12], we faced with the task of development of new methodical approach for the economic diplomacy for the purposes of innovation development.

So the objective of this research is to consider of economic diplomacy within the innovation development globalization and appropriate nation`s strategy and to develop main points of its application for GVCs as national security factor.

In this case we face with such three fundamental questions for researchers and nation policy makers:

1. What is the interrelation between the nation's security and globalization of innovations in the GVCs?

2. What tools can government use to promote the GVCs participation and collaboration across borders to help solve of the pressing nation's security challenges? 
3. How can government better promote of innovation objectives in the GVCs through the foreign policy?

4. How can the promoting of the GVCs participation helps government to achieve of different foreign policy goals?

\section{Methodology}

In the context of innovation internationalization and globalization modern innovations as a technological package (group of technologies, which work together) can be considered as an example of global value chain (GVC), in which technologies are created in different national innovation systems and have some role and importance in product, which is "made in the world". So we believe, that the technological package concept can be regarded as rational basis for cooperation promotion analysis within this research.

The relevance of GVCs to the national security is caused by understanding the fact, that the GVCs is a powerful driver of growth and productivity and support job creation. Within this governments are looking for new ways for the position of economic activities in these global networks of production and innovation with a view to safeguarding growth and employment at home [13].

Global value chains concept emergence has extended the input-output tables (IOTs) application, which allows to address the industries interdependencies across the different countries (or regions). The elements of multi-regional input-output (MRIO) can represent the flows between the country-industry pairs as well as provide the framework for the assessing of the country competitiveness both in terms of export performance and job creation [14].

Therefore, the primary focus moves to the differentiation of GVC in the context of the country's specialization. In this context, M. Porter [15] has defined the approach for the GVC creating as a collection of individual activities (such as design, production, marketing, distribution, service) of the firm, each of which needs to identify competitive advantages, costs and value added. We believe, that this approach should be applied at the macro level as well as in international comparative studies of competitiveness.

As a basic methodology of this research we propose to consider cross-sectoral international innovation linkages as the tools of technologies transfer analysis and innovation policy development as a system approach, which ensures an integrated development of high-tech products and associated processes from the product concept development to the disposal stage, which are based on the global value chains.

The indicated approach is very important for establishing the integrated national innovation systems, that as it was noted by us in previous studies on the example of the cross-sectoral intercluster cooperation and space industry development trends [3; 16], that is an important part of the innovation and technological security policy.

\section{Results}

The urgency of applying economic diplomacy to realize the objectives of innovation policy and economic security is caused by the fact, that in the modern world the place of industries and industry of the country is determined by its place in the international labor division. At the same time scientific and technological development and globalization are increasingly linking countries to global value creation networks (international division of innovation activities).

The strategic aspect of GVC can be considered on the examples of a number of high-tech industries, presented by R. Kaplinsky [17], including GVC of Apple iPhone. In this example the added value, created by China, is much lower, than that of other countries. The US supplies more components to China in value terms, than China adds to value when assembling the final product. At the same time, the contribution of other countries to the final value added is also significantly higher, than that of China. At the same time, China's export statistics will take into account the entire previous added value, and China's exports will be much higher, than those of other countries. The largest profit from this GVC is taken by the US, adding to the retail mark-up up to $64 \%$. On the consumer market, the product comes out at cost up to $\$ 500$, although its cost is only $\$ 179$. The similar examples of the modern high-tech products also illustrate the specialization factor.

S. Stephenson [6] also dispels the existed myth, that GVC are really global in their meaning. The researcher notes that by the innovation nature of their origin GVC is regional and is concentrated in three main centers: North America, Europe and East Asia. At the same time, the first two regions are mainly demand centers, and the latter 
is the supply center, although this trend is changing as China's economy moves towards the growth of consumer demand, and is also differentiated depending on the sectoral specifics.

From the European Central Bank experts [18]. which shows information about the production linkages of euro area with other country groups, and EU initiative "An integrated industrial policy for the globalization era" [19], which notes the importance of the GVC for EU industry and states: "EU needs to pay greater attention to the manufacturing value-chain. Industry is increasingly dependent on inputs of the raw material and intermediate goods, and is also crucially dependent on the business services industries, that add value and help to design market of the new goods and services. These new perspectives require a different approach for the industrial policy, that takes increased account of the interlinkages" [19].

Experts of OECD [13] notes, that the governments can help to the anchor production and the value creation by supporting of investment in skills and advanced manufacturing technologies, including in traditional industries, and through the policies, that the strengthen of networks and co-operation. At the same time old-style support policies can't be an answer to development goals as they ignore the interconnected nature of production in GVCs and necessity for the international competition and openness.

GVC is not uniform in terms of innovation and economic potential and the reasons for their formation are various factors that depend on industry specificity. At the same time, the main motivation of the leading companies in today's world is to reduce the cost of operations and risks in the context of globalized production.

In our previous studies we have shown the linkages between the technological security providing and increasing the efficiency of innovation development priorities selection [10].

The purposes of promotion participation in GVCs through the economic diplomacy are different [20]. For developed countries it deals with the ensuring the growth of employment and the desire to maintain of world technological leadership. For developing countries it is oriented on access to the global markets for ideas, capital, technology and HR.

Figure 1 illustrates the main purposes of economic diplomacy in innovation sector.

\section{National security problems}

- development of national scientific, technological and production capacity;

- development of priority areas of research and technology development, ensuring the competitiveness of the national economy;

- providing the privacy and protection of strategic facilities in importance of increased risk industries, in research organizations and enterprises whose activities are the subject of state secrets;

- export controls on proliferation of technologies and scientific developments;

- protection of intellectual property in the areas of foreign of scientific and technical cooperation;

- intelligence and counter-intelligence activity in technology, strategic importance.

\section{Global innovation trends}

- formation of single world scientific and technological space and market of high-tech products and services;

- formation of national innovation systems that are integrated internationally, covering a full range of institutions, ensuring the reproduction of innovation, development and technology transfer;

- specialization of individual countries on certain market of high-technology products;

- scientific communities of developed countries and developing countries, are increasingly oriented to joint research and development.

Economic diplomacy strategy:
- information and political-diplomatic support of projects on modernization and technological
development of the economy;
- mechanisms for supporting projects of enterprises entering foreign markets;
- the infrastructure for supporting high-tech exports, the creation of tools to support foreign
economic activity with infrastructure to support small and medium-sized innovative companies in
the regions;
- customs procedures and other restrictions when exporting high-tech products.

Figure 1 - Framework of economic diplomacy application in innovation system 
According to Eurostat [21] for development the economic diplomacy strategy for GVC we need to:

1) identify the international sourcing destinations, in particular the destinations of international sourcing of support functions using the business function approach;

2) evaluate the impacts of international sourcing activities on national economy - especially the impact on domestic employment;

3) describe the establishment and structuring of value chains and ways and strategies of going global.

Also we need to manage all complex of innovation communications in all levels of innovation processes. National innovation systems are components of the global innovation system, which has fragmentary nature. National innovative systems involve interconnected institutional structures of the technological, financial, tax, legal, social, educational order within which knowledge, technologies and leading practices are formed and commercialized.

On the basis of the world experience analysis to manage innovative systems, one suggests to observe the following effects of the international cooperation, which positively impact the national economy development:

1) effect of international innovation cooperation synergy, which is a combination of other innovation spill-over effects and intensification of the native investigations through the international innovation-technological cooperation.

Native scientific and research base and foreign technologies together provide the ability to realize synergetic synthesis of technologies, based on combination of the local scientific and research base, existing and potential demand for innovations and potential for foreign achievements.

2) effect of the innovation priorities optimization, based on the global experience, technological prognostications (foresight) and proper national priorities considering branch specific nature and social and economic development strategy;

Among the main effects of economic diplomacy in the value chains in innovation sectors we can name:

1. Effect of innovation and investment image, i.e. formation of the image about the country as a trusting partner through economic diplomacy under international cooperation, which is able to realize the audacious projects.

Image role of the country is very important for international business, particularly MNCs, technologies transfer through the involvement of which cannot only lead to development scientific and technical potential of some sectors, but also to providing the linked industries effective functioning in the middle or long-term perspective owing to the national economy innovation potential growth.

2. Cooperation readiness effect (analogically with the principle of Networked Readiness Index methodology), that the foresees experience and readiness (adaptiveness) to function in the international associations and partnerships, which provide to increase the knowledge and ideas synergy, based on the various social and economic conditions.

Now the specialization leads to more mutual dependence with other firms, organizations, suppliers, and thus MNCs more often involve the local suppliers and representatives from the scientific society to the cooperative collaboration. The peculiar feature of the modern stage is two- or multi-sided nature of the technological systems international transfer, and the firm may give and accept knowledge flows.

The experience proves that joint enterprises, created to carry out R\&D, have positive impact on the innovation development dynamics of separate sectors. For example, trade balance analysis of the USA sectors concludes, that in sectors where those participants are popular, who carry out cooperative $R \& D$, trade balance about 620 mln US dollars exceeds trade balance in sectors, where there are no the similar participants [22].

3. Effect of resources optimization owing to some $R \& D$ and orientation of free resources to new projects, described with more priority and potential.

4. Effect of the informational and analytical environment development, which provides that participants of the innovative relations have to estimate external and internal space, conduct informational discovery, to reveal future demands for innovations, to compare expenses of the competitive firms, using extremely all available resources at the intellectual property market, and choosing the most effective of them. 
One of the important aspects of successful creation and operation of economic diplomacy is marketing, providing international innovation communications effectiveness [23] through the quality data providing, optimization of resources and domestic resource mobilization from the external environment and effective involvement of economic agents to form the competitive value chains. This aspect creates a new terminology network marketing (NM), and when attention begins to be paid to the intercompany interactions - relationship marketing (RM).

Marketing interactions based on creating the network structures, including interactions processes between the different agents and generates intangible assets that increase the competitiveness. We suggest, that the network marketing in the innovation networks includes following levels:

1) marketing the ideas for innovation;

2) marketing the results of basic research;

3) marketing of intellectual property;

- marketing technology that can be part of a project or macro (e.g., technology, space industry);

- ultimate marketing technology, that is autonomous in application;

4) marketing of research projects;

5) marketing of innovation image [24];

6) marketing of innovation products.

In practical case of economic diplomacy application we can name US, that tries to push innovation models and the most important technology platforms to other states around the world.

Also it is necessary to mention so called "cooperative development" in the economic diplomacy of China, i.e. owing to economic complementarity of China and other countries to promote business collaboration, to create conditions to gain mutual benefits and community by interests.

Some example of innovation economic diplomacy can be found in [25]. Within the innovation economic diplomacy Netherlands' government focuses primarily on strengthening the international market position of domestic entrepreneurs, operating in priority sectors (energy, creative industry, life sciences, high tech, logistics, propagation materials, water, agri-food, chemicals). In Netherlands this is realized through such main activities:
- efforts for the attraction of foreign companies and top talents to Netherlands as they provide important stimulus for Dutch knowledge economy;

- presenting of the options menu, offering entrepreneurs the choice of various instruments, responding to their specific requirements;

- SMEs wishing to start activities abroad can obtain various types of assistance. In 2012, enterprise centers will be established, offering to the entrepreneurs a single point of the contact to access extensive information from the network partners and the market parties;

- Netherlands has the extensive international network of missions to promote the interests of domestic businesses abroad. These include embassies, consulates and the Netherlands Business Support Offices. Staff from these missions make the contacts with the overseas governments to address such issues as market access and restrictive rules or regulations.

\section{Conclusions}

Globalization is the main driving force for the economic diplomacy development and positively influences to international competition and activates states to promote and protect their national interests in the world market and global innovation system. At the same time, globalization increases the role of economic diplomacy, raising it to new quantitative and qualitative level, attracting the innovation resources of individual states to obtain the final product in the process of its creation in the interests of all countries, and prevents the monopolization of the advantages of globalization by some countries.

The principle of innovative development strategic purpose preconditions necessity to have and to achieve strategic aims of the innovative development in economy. They are formed in the system to control target and proper linear, functional and providing management subsystems both at the state, regional and enterprises level, actively performing innovative projects, based on state and private partnership.

In further studies we will consider the basics of economic diplomacy strategy for the innovation system development purposes. 


\section{References}

1. Hormats, R. (2013). The Road to an Effective Innovation Diplomacy. The Huffington Post. Retrieved February 20, 2017, from http://www.huffingtonpost.com/bob-hormats/the-road-to-an-effective_b_3306749.html

2. Jewell, C., \& Wunsch-Vincent, S. (2015, September). Global Innovation Index 2015: Effective Innovation Policies For Development. WIPO Magazine, 5. Retrieved from http://www.wipo.int/wipo_magazine/en/2015/05/article_0002.html

3. Omelyanenko, V. A. (2016). Optimizacija tehnologicheskogo paketa kosmicheskoj otrasli pri integracii v global'nye cepochki dobavlennoj stoimosti [Technology package optimization in space industry in case of integration into the global value chain]. GISAP: Economics, Jurisprudence and Management, 10, 10-13 (in Russian)

[Омельяненко, В. А. (2016). Оптимизация технологического пакета космической отрасли при интеграции в глобальные цепочки добавленной стоимости. GISAP: Economics, Jurisprudence and Management, 10, 10-13].

4. Leijten J. (2016, September 12). Is there something like innovation diplomacy? El-CSID. doi: 10.5281/zenodo.154082

5. Krosbi, J. (Ed.). (2015). V bor'be za mesto v global'noj cepochke sozdanija stoimosti [In the struggle for a place in the global value chain]. Bridges, 8(3), 1-32 (in Russian)

[Кросби, Э. (Ред.). (2015). В борьбе за место в глобальной цепочке создания стоимости. Мосты, 8(3), 1-32 ].

6. Stephenson, S. (2013). Global value chains: the new reality of international trade. Geneva: ICTSD\&WEF.

7. Omelyanenko, V. A. (2014). Analysis of Potential of International Inter-Cluster Cooperation in HighTech Industries. International Journal of Econometrics and Financial Management, 2(4), 141-147.

8. Prokopenko, O. V., \& Omelyanenko, V. A. (2013). Mizhnarodniy faktor zabezpechennia tehnologichnoi bezpeki derzhavi [International factor of state technological security]. In E. Hlobystov (Ed.), Ekonomichna bezpeka derzhavy: mizhdyscyplinarny pidhid (pp. 89-98). Cherkasy: Vydavets Yu. A. Chabanenko (in Ukrainian)

[Прокопенко, О. В., \& Омельяненко В. А. (2013). Міжнародний фактор забезпечення технологічної безпеки держави. В Є. В. Хлобистов, Економічна безпека держави: міждисциплінарний підхід (с. 89-98). Черкаси: Видавець Ю. А. Чабаненко].

9. Krapyvny, I. V., Omelyanenko, V. A., \& Vernydub, N. O. (2015). International innovation networks as new stage of innovation development. Economic Processes Management: International Scientific EJournal, 1, 1-12.

10. Omelyanenko, V. A. (2016). Innovation priorities optimization in the context of national technological security ensuring. Marketing and management of innovations, 4, 226-234.

11. Chesbrough, H. W. (2003). Open Innovation: The New Imperative for Creating and Profiting from Technology. Cambridge: Harvard Business School Publishing.

12. Troyan, I. A. (2016). Koncepciia ekonomicheskoy diplomatii kak instrument vneshneekonomicheskoy politiki [The concept of economic diplomacy as an instrument of foreign economic policy]. Problemy jekonomiki i menedzhmenta, 6, 129-138 (in Russian) [Троян, И. А. (2016). Концепция экономической дипломатии как инструмент внешнеэкономической политики. Проблемы экономики и менеджмента, 6, 129-138].

13. OECD. (2013). Interconnected economies: benefiting from global value chains: synthesis report. Retrieved from https://www.oecd.org/sti/ind/interconnected-economies-GVCs-synthesis.pdf

14. Mauro, F., Plamper, H., \& Stehrer, R. (2013, August). Global value chains: a case for Europe to cheer up. Retrieved from 
https://www.ecb.europa.eu/home/pdf/research/compnet/policy_brief_3_global_value_chains.p df?fcccc5651bee912e1698e1019c8b3969

15. Porter, M. (2001). Konkurencija [Competition]. Moscow: Williams (in Russian)

[Портер, М. (2001). Конкуренция. Москва: Вильямс]

16. Omelyanenko, V. A. (2015). Scientific and methodic bases of high technologies international transfer potential analyzing in metallurgy. Metallurgical and Mining Industry, 3, 66-69.

17. Kaplinsky, R. (2013, November). Global value chains, where they came from, where they are going and why this is important. Innovation, Knowledge, Development Working Papers, 68, 1-28.

18. João, A., Cappariello, R., Stehrer, R. (2015, March). Global value chains: a view from the euro area. European Central Bank. Working Paper Series, 1761.

19. Commission to the European Parliament, the Council, the European Economic and Social Committee and the Committee of the Regions. (2010). An Integrated Industrial Policy for the Globalization Era Putting Competitiveness and Sustainability at Centre Stage (Publication No 0614). Retrieved from http://eur-lex.europa.eu/legal-content/EN/TXT/?uri=CELEX:52010DC0614

20. Danilin, I. V. (2012). Diplomatiia i innovacii: snachala Ideia [Diplomacy and Innovation: Idea First]. Russia in global politics, 3 (in Russian)

[Данилин, И. В. (2012). Дипломатия и инновации: сначала Идея. Россия в глобальной политике, 3].

21. Eurostat (n .d.). Global value chains. Retrieved February 10, 2017, from http://ec.europa.eu/eurostat/statistics-explained/index.php/Global_value_chains

22. DeCourcy, J. (2007). Research Joint Ventures and International Competitiveness: Evidence from the National Cooperative Research Act. Economics of Innovation and New Technology, 16(1), 51-65. doi: 10.1080/10438590600661822

23. Prokopenko, O., Eremenko, Yu., \& Omelyanenko, V. (2014). Role of international factor in innovation ecosystem formation. Economic Annals-XXI, 3/4(2), 4-7.

24. Sadovy, V. O., Mogylna, N. O., \& Omelyanenko, V. A. (2009). Imidzh regionu yak faktor zaluchennia inozemnih i vnutrishnih investiciy [The image of the region as a factor in attracting foreign and domestic investment]. Mechanism of Economic Regulation, 2(3), 282-287 (in Russian). [Садовий, В. О., Могильна, Н. О., \& Омельяненко, В. А. (2009). Імідж регіону як фактор залучення іноземних і внутрішніх інвестицій. Механізм регулювання економіки, 2(3), 282287].

25. Government of Netherlands. (n. d.). Economic diplomacy. Retrieved February 15, 2017, from https://www.government.nl/topics/enterprise-and-innovation/contents/economic-diplomacy 